\title{
Reformulasi Pengaturan Leniency Program dalam Hukum Persaingan Usaha Indonesia (Perbandingan Leniency Program Di Brazil)
}

\section{Devy Monica $^{1}$, Hanif Nur Widhiyanti ${ }^{2}$, Afifah Kusumadara ${ }^{3}$}

${ }^{1}$ Devy Monica; Fakultas Hukum Universitas Brawijaya; Jl. MT. Haryono 169; Malang; 65145; Indonesia.

${ }^{2}$ Hanif Nur Widhiyanti; Fakultas Hukum Universitas Brawijaya; Jl. MT. Haryono 169; Malang; 65145; Indonesia.

${ }^{3}$ Afifah Kusumadara; Fakultas Hukum Universitas Brawijaya; Jl. MT. Haryono 169; Malang; 65145; Indonesia.

\begin{tabular}{l} 
A R T I C L E I N F O \\
\hline Article history: \\
Received 2018-09-02 \\
Received in revised form \\
2018-10-10 \\
Accepted 2018-12-01
\end{tabular}

Kata kunci: Pengaturan, Leniency Program, Hukum Persaingan Usaha

Keywords: Arrangement, Leniency Program, Business Competition Law

\section{Abstrak}

Penelitian ini dilatarbelakangi oleh dimasukkannya permasalahan mengenai Leniency Program dalam RUU tentang Larangan Praktik Monopoli dan Persaingan Usaha yang Tidak Sehat. Karakteristik kartel yang utama adalah tingkat kerahasiaan yang tinggi. Tertutupnya informasi bagi pihak luar, dan komunikasi yang dilakukan secara diam-diam. Semakin menambah kesulitan bagi KPPU untuk mendapatkan bukti langsung. Sehingga, untuk mengatasi hal tersebut, selama ini Putusan KPPU dalam perkara kartel, KPPU menggunakan alat bukti tidak langsung beberapa putusan ada yang dibatalkan oleh PN dan atau $M A$, disatu sisi juga terdapat yang di kuatkan oleh PN dan atau MA. Negara Brazil merupakan negara di Amerika Latin yang memiliki Leniency Program yang sukses dibandingkan dengan negara lainnya. Tujuan dari penulisan ini dengan mengetahui pengaturan Leniency Program di Brazil, dapat dijadikan referensi dalam pembaharuan hukum persaingan usaha di Indonesia.

\section{Abstract}

This paper is motivated by the inclusion of problems regarding the Leniency Program in the RUU tentang Larangan Praktek Monopoli dan Persaingan Usaha yang Tidak Sehat. The main cartel characteristic is the high level of confidentiality. Closed information for outsiders, and communication made secretly. Based on fact, KPPU is having trouble to obtain direct evidence. Therefore, to overcome this matter, during this KPPU Decision in cartel case, KPPU uses indirect evidence some of the decisions are canceled District Court and / or Supreme Court, on the one hand there are also strengthened by District Court and / or Supreme Court. Brazil is a country in Latin America that has a successful Leniency Program. The purpose of this paper by knowing the Leniency Program setting in Brazil, can be used as reference in the renewal of business competition law in Indonesia.

Corresponding Author:

Devy Monica

E-mail address: Monicadevy88@gmail.com

DOI: https://doi.org/10.26905/idjch.v9i2.2725 


\section{Latar Belakang}

Pada hakikatnya kartel dilakukan pelaku usaha untuk mendapatkan keuntungan, kartel termasuk sebagai salah satu bentuk kerjasama antara sejumlah perusahaan yang bersepakat untuk mengendalikan jumlah produksi atas suatu barang dan harga atas suatu barang dan jasa (KPPU, 2011). Terdapat syarat yang harus dipenuhi oleh pelaku usaha yang melakukan kartel adalah perjanjian antara pelaku usaha yang satu dengan pelaku usaha yang lain untuk bersepakat melakukan kartel yang bertujuan untuk memperoleh keuntungan yang lebih tinggi (Rachmadi, 2013). Pelaku usaha dalam melakukan kartel dapat dilakukan secara eksplisit maupun secara diam-diam. (KPPU, 2011).

Upaya pembuktian kartel terdapat perbedaan dengan pembuktian pelanggaran perkara persaingan usaha lainnya. Dalam upaya mengungkap kartel otoritas persaingan biasanya menggunakan alat bukti tidak langsung yang telah lazim digunakan di semua negara. Bentuk dari bukti tidak langsung terbagi menjadi dua, yakni berupa bukti komunikasi dan bukti ekonomi. Penggunaan bukti tidak langsung telah lazim digunakan oleh otoritas penegak hukum persaingan usaha, otoritas penegak hukum persaingan usaha tidak perlu menyajikan bukti lisan dan tertulis, hal tersebut dapat dipahami karena sangat sering dalam kasus kartel, bukti semacam itu tidak tersedia (OECD, 2006).

Komisi Pengawas Persaingan Usaha telah memiliki kewenangan sesuai dengan pasal 35 untuk dapat melakukan penilaian terhadap perjanjian yang dilakukan oleh pelaku usaha yang diduga dapat mengakibatkan terjadinya praktek monopoli dan persaingan usaha yang tidak sehat. KPPU dalam melakukan tugas dan wewenangnya tidak dapat bertindak sembarangan karena apabila KPPU melakukan kesalahan dalam mengonstantir, mengualifisir dan mengonstituir nantinya akan dapat menimbulkan konsekuensi pembatalan putusan KPPU oleh PN dan atau MA. KPPU menjadi aktor utama sebagai pihak yang berkedudukan untuk menilai perjanjian yang dilakukan oleh pelaku usaha yang terindikasi melakukan kartel. Pada akhirnya, perjanjian tersebut dapat digunakan sebagai bukti telah terjadinya kartel.

Namun, kenyataan yang terjadi terdapat tiga Putusan KPPU yang menggunakan alat bukti tidak langsung yang dibatalkan oleh PN dan atau MA, antara lain sebagai berikut: Putusan KPPU tentang kartel bahan bakar penumpang (No. 25/2009), Putusan KPPU No. 24 Tahun 2009 tentang kartel minyak goreng (No. 24/2009), dan Putusan KPPU tentang Kartel Obat Hipertensi (No. 17/2010). Sedangkan untuk putusan KPPU yang dikuatkan oleh PN dan atau MA, antara lain sebagai berikut: Putusan KPPU tentang Kartel Ban (No. 08/2014), Putusan KPPU tentang Kartel Yamaha dan Honda (No. 04/2016), dan Putusan KPPU tentang Kartel Daging Sapi Impor (No. 10/2015).

Adanya perbedaan pandangan hakim terkait penggunaan alat bukti tidak langsung, KPPU dapat menggunakan Leniency Program sehingga nantinya akan mendapatkan alat bukti langsung yang diserahkan oleh pelaku usaha yang melakukan kartel tersebut. Pada dasarnya, leniency program akan diberikan kepada pelaku usaha yang mengaku telah melakukan kartel akan mendapatkan pengurangan hukuman dibandingkan pelaku usaha yang tidak mau mengaku. Dalam penelitian ini akan mencoba membandingkan pengaturan Leniency Program di Brazil agar dapat dijadikan referensi dalam hukum persaingan usaha di Indonesia. Dalam Brazilian Competition Law no. 8.894 of 1994, dalam tujuan pembentukan undang-undang ini berupaya mendahulukan kepentingan konsumen dengan cara memberikan manfaat kepada anggota kartel yang ingin mengajukan keterangan tentang perilaku illegalnya dam serta kepada anggota kartel yang akan bekerjasama dengan otoritas persaingan (Secretariat of CADE, 17). Leniency Program di Brazil telah diterapkan kurang lebih selama 16 tahun, dan telah menjadi salah satu alat 
investigasi yang efektif untuk mendeteksi kartel di Brazil (Athayde, Andressa, 2016). Adapun yang menjadi permasalahan yang hendak diangkat dalam penelitian ini adalah bagaimana seharusnya pengaturan Leniency Program di Indonesia.

\section{Metode}

Dalam penelitian ini menggunakan jenis penelitian yuridis normatif. Dalam melakukan penelitian ini, penulis melakukan beberapa pendekatan antara lain: perundang-undangan (statute approach), pendekatan kasus (case approach), dan pendekatan perbandingan (comparative approach). Adapun jenis bahan hukum yang digunakan terdiri atas, bahan hukum primer, sekunder dan tersier. Sumber hukum primer terdiri dari: UUD NRI Tahun 1945, Kitab Undang-Undang Hukum Perdata, Reglemen Indonesia yang Diperbaharui (R.I.B) atau Herzien Inlandsch Reglement (H.I.R), UU No. 8 Tahun 1981 tentang Hukum Acara Pidana, UU No. 5 Tahun 1999 tentang Larangan Praktek Monopoli dan Persaingan Usaha yang Tidak Sehat, Keppres No. 75 Tahun 1999, Peraturan Komisi No. 1 Tahun 2010, Peraturan Komisi No. 4 Tahun 2011, Peraturan Mahkamah Agung No. 3 Tahun 2005. Sumber Hukum Sekunder yang digunakan dalam penelitian ini berupa buku-buku teks hukum persaingan usaha, buku teori hukum, jurnal-jurnal hukum persaingan usaha, leniency program, serta komentar atas putusan pengadilan yang berkaitan dengan tema hukum persaingan usaha, hukum pembuktian dan leniency program. Sedangkan sumber hukum tersier menggunakan Kamus yakni KBBI.

\section{Pembahasan}

Setiap peraturan perundang-undangan dalam pembentukannya telah melewati pertimbangan-pertimbangan oleh para pembuat peraturan perundang-undangan. Pertimbangan tersebut lazim disebut dengan konsiderans, kon- siderans merupakan bagian awal dalam peraturan perundang-undangan yang berisi mengenai uraian singkat mengenai pokok pikiran yang menjadi pertimbangan dan alasan pembentukan peraturan perundang-undangan (Yani, 2013). Dalam kasus Leniency Program di Indonesia, berdasarkan uraian latar belakang diatas, maka akan disusun konsiderans yang akan berbunyi sebagai berikut:

Peraturan Pemerintah Nomor... Tahun... tentang Penerapan Leniency Program dalam Mengungkap Kartel di Indonesia.

"Menimbang: bahwa untuk mengoptimalkan penegakan hukum kartel dalam bidang hukum persaingan usaha serta untuk melaksanakan ketentuan Pasal 70 tentang Leniensi RUU Tentang Larangan Praktik Monopoli dan Persaingan Usaha Tidak Sehat, perlu menetapkan Peraturan Pemerintah tentang Penerapan Leniency Program dalam mengungkap kartel di Indonesia"

Langkah selanjutnya adalah merumuskan ketentuan umum dalam Peraturan Pemerintah tersebut, merumuskan definisi dalam ketentuan umum merupakan hal yang penting dan tidak bisa dikesampingkan oleh Pembuat Peraturan Perundang-Undangan. Definisi istilah dalam peraturan perundang-undangan berfungsi untuk membatasi ruang lingkup perihal yang didefinisikan. Adapun definisi-definisi yang nantinya akan terdapat dalam Peraturan Pemerintah antara lain:

\section{a. Pelaku Usaha}

Definisi Pelaku Usaha yang digunakan akan menggunakan definisi pelaku usaha yang terdapat dalam RUU (RUU tentang Larangan Praktik Monopoli dan Persaingan Usaha Tidak Sehat). Hal itu disebabkan oleh definisi pelaku usaha yang terdapat dalam UU Nomor 5 Tahun 1999 belum dapat menjangkau kewenangan KPPU untuk menindak pelaku usaha yang berasal dari Luar teritorial Indonesia yang dimana tindakan mereka 
dapat menimbulkan monopoli dan persaingan usaha tidak sehat di Indonesia.

Pasal 1 huruf e UU Nomor 5 Tahun 1999, pelaku usaha didefinisikan sebagai berikut:

"Pelaku usaha merupakan orang perorangan atau badan usaha, yang telah berbentuk badan hukum atau tidak yang didirikan dan berkedudukan atau melakukan kegiatan dalam wilayah hukum negara Republik Indonesia, baik sendiri maupun bersama-sama melalui perjanjian, menyelenggarakan berbagai kegiatan usaha di bidang ekonomi"

Persoalan tentang definisi pelaku usaha termasuk dalam poin perubahan UU No.5/1999. Dalam rumusan UU No. 5/1999, khususnya dalam Pasal mengenai pelaku usaha, Indonesia tidak secara eksplisit menyebutkan bahwa yang dimaksud dengan pelaku usaha dapat juga berasal dari pelaku usaha dari Luar Negeri. Salah satu ketentuan yang akan diubah adalah mengenai persoalan definisi pelaku usaha yang diberikan oleh UU No./ 1999 dapat menghambat penegakan hukum persaingan usaha, khususnya terhadap praktek anti persaingan yang dilakukan oleh pelaku usaha asing/pelaku usahayang berdomisili hukum di luar wilayah Indonesia, tetapi praktek anti persaingan usaha yang dilakukan oleh pelaku usaha tersebut berdampak bagi pasar dan perekonomian Indonesia (DPR, 84).

Rancangan UU Nomor 5 Tahun 1999 tentang Larangan Praktik Monopoli dan Persaingan Usaha Tidak Sehat, tepatnya dalam Pasal 1 angka 6, definisi pelaku usaha diperluas menjadi sebagai berikut:

"Pelaku usaha merupakan orang perorangan atau badan usaha, atau badan usaha yang telah berstatus badan hukum yang didirikan dan berkedudukan atau melakukan kegiatan baik di dalam maupun di luar wilayah hukum Negara Republik Indonesia yang mempunyai dampak terhadap perekonomian Indonesia, baik sendiri-sendiri maupun bersama-sama melalui perjanjian, menyelenggarakan berbagai kegiatan usaha di bidang ekonomi"

Definisi pelaku usaha diatas, nampak bahwa unsur subyek hukum dalam pelaku usaha telah diperluas. Unsur-unsur yang terdapat dalam definisi tersebut: setiap orang perorangan atau badan usaha, baik yang berbentuk badan hukum atau bukan badan hukum; Didirikan dan berkedudukan; Atau melakukan kegiatan baik di dalam maupun di luar wilayah hukum Negara Republik Indonesia; Yang mempunyai dampak terhadap perekonomian Indonesia; Baik sendiri-sendiri maupun bersama-sama melalui perjanjian; Menyelenggarakan berbagai kegiatan usaha di bidang ekonomi.

Persaingan Usaha Tidak Sehat dalam Pasal 1 huruf $\mathrm{f}$ UU Nomor 5 Tahun 1999 didefinisikan sebagai:

"persaingan antar pelaku usaha dalam menjalankan produksi dan atau pemasaran barang dan atau jasa yang dilakukan dengan usaha tidak jujur atau melawan hukum atau menghambat persaingan usaha"

Pasar, pelaku usaha seharusnya melakukan tindakan-tindakan dalam kegiatan usahanya untuk dapat mendapatkan hati konsumen agar memilih produk dari mereka. Secara umum terdapat 2 jenis persaingan usaha, persaingan usaha terdiri dari: persaingan usaha sehat (healthy competition) yakni pelaku usaha benar-benar bersaing dengan pelaku usaha yang lainnya dengan upaya memperbaiki diri sendiri menambah bonus-bonus dan lain-lain dan persaingan usaha tidak sehat (unfair competition), yang dilakukan dengan cara yang tidak baik dan untuk mendapatkan keuntungan sebanyakbanyaknya.

Definisi tentang persaingan usaha tidak sehat penting untuk dicantumkan, hal tersebut dikarenakan beberapa faktor: Persaingan usaha tidak sehat dapat menimbulkan kerugian bagi konsumen 
dan sesungguhnya telah tidak sesuai dan bertentangan dengan nilai ke 5 Pancasila yakni keadilan sosial; Pelaku usaha yang menjalankan kegiatan usahanya dengan tidak melanggar hukum, melakukan bisnis secara fair dapat dibatasi pergerakannya oleh pelaku usaha yang melanggar hukum; Konsumen akan kehilangan inovasi dan penawaran terbaik dari pelaku usaha, karena pelaku usaha tidak perlu bersaing satu dengan yang lainnya untuk mendapatkan hati konsumen.

\section{c. Leniency Program}

Leniency Program merupakan pengurangan hukuman administrasi bagi pelaku usaha yang mengakui kesalahannya sebelum proses penyelidikan di KPPU. Di Indonesia, Leniency Program akan dapat berjalan efektif dengan menuntut keaktifan dari pihak yang terikat pada kartel untuk memberikan keterangan berupa kesaksian dan membeberkan alat bukti perkara kartel sebelum KPPU melakukan investigasi secara mendalam. Pentingnya masalah definisi Leniency Program, hal ini disebabkan oleh beberapa faktor: Di Indonesia Leniency Program belum mendapatkan pengaturan yang jelas dan komprehensif. Sehingga nanti dapat menimbulkan masalah dikemudian hari apabila perumusan pasal tentang definisi Leniency Program masih tidak jelas. Bidang hukum persaingan usaha khususnya dalam Pengaturan dalam UU No. 5/ 1999 pada Bab VIII bagian sanksi yakni dalam Pasal 47 mengatur tentang tindakan administratif dan Pasal 48 tentang pidana pokok, dan yang terakhir mengatur tentang pidana tambahan dalam Pasal 49. Di Indonesia perlu dikaji lagi apakah Leniency Program hanya untuk pengurangan denda administrasi saja, dan tidak menyentuh ranah denda pidana kurungan. Mengingat, Dalam pengaturan pasal 48 UU No 5/1999, beberapa pasal-pasal yang dapat diberlakukan Leniency Program dapat juga dikenakan sanksi pidana. Adapun besaran denda dan pidana pokok adalah sebagai berikut:

(1) Pelanggaran terhadap ketentuan Pasal 4 (oligopoli), Pasal 9 (pembagian wilayah), pasal 10 (pemboikotan), pasal 11 (kartel), pasal 12 (trust), pasal 13 (oligopsoni), Pasal 14 (integrasi vertikal), Pasal 16(perjanjian yang dilakukan dengan pihak luar negeri), pasal 17 (monopoli), pasal 18 (monopsoni), Pasal 19 (penguasaan pangsa pasar), Pasal 25 (persekongkolan untuk menghambat produksi dan/atau pemasaran barang dan jasa), Pasal 27 (pemilikan saham mayoritas), dan Pasal 28 (penggabungan, peleburan dan pengambilalihan) diancam pidana denda serendah-rendahnya Rp 25.000.000.000,00 (dua puluh lima miliar rupiah) dan setinggi-tingginya Rp 100.000.000.000,00 (seratus miliar rupiah), atau pidana kurungan pengganti denda selama-lamanya 6 (enam) bulan;

(2) Pelanggaran terhadap ketentuan Pasal 5 (perjanjian penetapan harga), Pasal 6 (diskriminasi harga), Pasal 7 (jual rugi), Pasal 8 (Penetapan harga jual kembali), Pasal 15 (perjanjian tertutup), Pasal 20 (pemasokan barang dengan jual rugi), Pasal 21 (kegiatan penetapan biaya produksi secara curang), Pasal 22 (persekongkolan tender), Pasal 23 (persekongkolan mendapatkan informasi), Pasal 24 (persekongkolan untuk menghambat produksi), dan Pasal 26 (jabatan rangkap) Undang-Undang ini diancam pidana denda serendah-rendahnya Rp 5.000.000.000,00 (lima miliar rupiah) dan setinggi-tingginya Rp 25.000.000.000,00 (dua puluh lima miliar rupiah), atau pidana kurungan pengganti denda selama-lamanya 5 (lima) bulan;

(3) Pelanggaran terhadap ketentuan Pasal 41 (pembuktian) Undang-undang ini diancam pidana denda serendah-rendahnya $\mathrm{Rp}$ 1.000.000.000,00 (satu miliar rupiah) dan setinggi-tingginya Rp 5.000.000.000,00 (lima miliar rupiah), atau pidana kurungan pengganti denda selama-lamanya 3 (tiga) bulan.

RUU Nomor 5 Tahun 1999, adapun pasalpasal yang dapat dikenakan Leniency Program sebagai berikut: 
(1) Pasal 4 (Oligopoli) dapat dikenakan pasal 48 ayat (1); (2) Pasal 5 (Perjanjian Penetapan Harga) dapat dikenakan pasal 48 ayat (2); (3) Pasal 7 (Jual Rugi) dapat dikenakan pasal 48 ayat (2); (4) Pasal 9 (Pembagian Wilayah) dapat dikenakan pasal 48 ayat (1); (5) Pasal 10 (Pemboikotan) dapat dikenakan pasal 48 ayat (1); (6) Pasal 11 (Kartel) dapat dikenakan pasal 48 ayat (1); (7) Pasal 12 (Trust) dapat dikenakan pasal 48 ayat (1); (8) Pasal 13 (Oligopsoni) dapat dikenakan pasal 48 ayat (1); (9) Pasal 15 (Perjanjian Tertutup) dapat dikenakan pasal 48 ayat (2); (10) Pasal 16 (Perjanjian yang dilakukan Dengan Pihak Luar Negeri) dapat dikenakan pasal 48 ayat (1); (11) Pasal 18 (Monopsoni) dapat dikenakan pasal 48 ayat (1).

KPPU hanya berwenang untuk memberikan denda administrasi. Dalam perkara kartel, KPPU memiliki kewenangan untuk mempidanakan pelaku usaha yang terbukti telah melakukan kartel (Psl 47 UU No. 5/1999). Kewenangan yang dimiliki oleh KPPU ini timbul sejak setelah keputusan KPPU telah memiliki kekuatan hukum tetap, namun Pelaku Usaha tidak menjalankan keputusan KPPU. Pihak yang melaksanakan pemberian denda pidana adalah unsur penegak hukum kepolisian dan kejaksaan.

Terdapat penelitian tesis milik Hersen Monarchy yang berjudul "Reformulasi Pidana Kurungan Pengganti Denda dengan Pidana Pengawasan". Dalam penelitian ini menyoroti pemberian sanksi berupa sanksi pidana sesuai dalam pasal $48 \mathrm{UU}$ No.5 Thn 1999 yang dirasakan sudah ketinggalan zaman dan sudah saatnya di ubah. Peneliti menggunakan metode perbandingan dengan pengaturan Leniency Program di Amerika Serikat dan Jepang.

Di Amerika Serikat perspektif penegakan hukum kartel menggunakan perspektif hukum pidana, mengacu pada Section I Sherman Act, pidana denda akan yang akan diberikan sebesar paling besar USD 100 juta yang diberikan kepada subyek hukum perusahaan, dan untuk subyek hukum individu akan diberikan pidana denda paling besar USD 1 juta dan atau pidana penjara maksimal 10 (sepuluh) (Christina, 2012). Ketentuan yang berbeda di Jepang, untuk subyek hukum korporasi yang terlibat dalam kartel sesuai dengan Antimonopoly Law akan diberikan pidana denda paling besar $¥ 500$ juta, sementara subyek hukum individu akan dikenakan pidana denda maksimal $¥ 5$ juta pemberian denda tersebut dapat diberikan pelaku usaha secara kumulatif maupun alternatif dengan pidana penjara maksimal 5 (lima) tahun (Muladi, dkk, 2005).

Peneliti Hersen berpendapat dalam rangka mengubah untuk mengatur kembali/mereformulasi ketentuan tentang sanksi pidana untuk dapat diterapkan dalam praktek kartel di masa depan perlu untuk segera dilaksanakan, hal ini sejalan dengan teori tujuan pemidanaan yaitu dengan 2 (dua) cara alternatif. Pertama dengan memperberat sanksi pidana sesuai dengan pengaturan Amerika Serikat dan Jepang kemudian menggunakan Leniency Program tetapi disesuaikan dengan keadaan perekonomian di Indonesia. Dan kedua, menggantin sanksi pidana kurungan pengganti denda yang terdapat dalam Pasal 48 ayat (1) UU Nomor 5 Tahun 1999 dengan pidana pengawasan dan pidana denda.

Hukum pidana menurut W.L.G Lemaire, hukum berisi norma (keharusan-keharusan, larangan-larangan) yang oleh pihak legislatif sebagai pemrakarsa pembuat undang-undang telah disertai sanksi (penderitaan yang bersifat khusus) (Muladi, Barda, 2005). Dalam pengaturan pasal 10 KUHP,telah mengatur jenis-jenis dari pidana.

KUHP yang masih berlaku, tidak terdapat pengaturan tentang mekanisme dan tata cara pidana pengawasan. Pidana pengawasan dapat ditemukan dalam RUU KUHP yang sampai dengan saat ini masih dalam tahapan penyusunan dan rencananya akan disahkan pada bulan Agustus 2018. Keuntungan-keuntungan dari adanya penerapan pidana pengawasan adalah sebagai berikut: Terpidana diberikan kesempatan untuk memperbaiki 
diri; Membuat terpidana dapat melakukan dan melanjutkan kebiasaan dalam hidupnya; Menghilangkan dan mencegah adanya cap sosial dari masyarakat terhadap dirinya; Memberi kesempatan terpidana untuk menjadi pelaku usaha yang dilakukan demi kelangsungan hidup; Menghemat biaya; Optimalisasi fasilitas untuk melakukan rehabilitasi terhadap terpidana.

Terdapat kriteria-kriteria pasal-pasal yang dapat dijatuhi pidana pengawasan, antara lain (RUU KUHP, 52): Terdapat ketentuan yang menyatakan bahwa hanya untuk Tindak Pidana maksimal dan tidak melebihi dari 7 (tujuh) tahun yang dapat dijatuhi pidana pengawasan. Terpidana hanya dapat diberikan Pidana pengawasan maksimal selama 3 (tiga) tahun. Perlunya koordinasi dari Pejabat Pembina, Pemerintah Daerah maupun lembaga sosial demi terwujudnya pidana pengawasan. Pidana pengawasan dapat berdiri sendiri.

Jika merujuk rumusan pasal dalam RUU diatas, bagi pelaku kartel akan menerima pidana kurungan dan denda. Munculnya wacana baru tentang pidana pengawasan dapat dipertimbangkan dalam merumuskan pasal-pasal yang terkait dengan hukuman di bidang persaingan usaha. Semua bentuk pidana (pidana mati, pidana penjara, pidana kurungan, dan pidana tutupan) masing-masing mempunyai nilai positif dan nilai negatif. Kasus kartel, alangkah baiknya ancaman pidana terdiri dari 3 (tiga) yakni pidana kurungan, pidana denda dan pidana pengawasan.

Hersen, terutama pada gagasan untuk mengganti rumusan dalam ayat 1 pasal 48 UU No. 5 Tahun 1999 yang telah dibahas sebelumnya menjadi hanya pidana pengawasan dan pidana denda. Melihat karakteristik kartel dan kerugian yang di terima oleh masyarakat akibat adanya kartel, dengan menghilangkan pidana kurungan akan mengurangi ketakutan pelaku usaha yang memilih Indonesia sebagai wilayah untuk melakukan kegiatan ekonomi. Pidana kurungan dapat membuat pelaku usaha berpikir dua kali (untuk efek jera) untuk melakukan pelanggaran di bidang persaingan usaha.

\section{Ruang Lingkup Leniency Program}

Naskah akademik tentang perubahan UU No. 5 Thn 1999 (Larangan Praktik Monopoli dan Persaingan Usaha Tidak Sehat) yang seyogyanya menjadi rujukan awal dalam pembuatan UndangUndang tentang Larangan Praktik Monopoli dan Persaingan Usaha Tidak Sehat tidak membahas secara komprehensif pasal demi pasal yang dapat dimasukkan dalam pasal-pasal yang dapat dikenakan Leniency Program. Namun, dalam RUU telah ditentukan pasal-pasal yang dapat dikenakan Leniency Program. Terdapat berbagai pendapat dari para ahli tentang ruang lingkup Leniency Program di Indonesia:

a. Lantiko Hikma Suryatama (jabatan selaku Senior Associate dari Firma Hukum HADS Partnership Law Office)

Rumusan Pasal-Pasal dalam Leniency Program hanya terbatas pada kartel saja, ruang lingkup Leniency Program yang terdapat dalam RUU terlalu luas dan tidak signifikan. Latinko mengatakan, Leniency Program cocok untuk diterapkan bagi kartel (perjanjian penetapan harga dan pengaturan produksi). Sedangkan pasal yang lain, misalnya tentang oligopoli dirasa kurang cocok untuk Leniency Program.

b. Ditha Wiradiputra (selaku jabatan Direktur Eksekutif di Lembaga Kajian Persaingan dan Kebijakan Usaha FH-UI)

Berbeda dengan ruang lingkup Leniency Program terhadap hardcore cartel yakni kartel harga, kartel wilayah, kartel kuota dan persekongkolan tender. Di Indonesia terdapat sedikit perbedaan, hal ini dikarenakan dalam Hukum Persaingan Usaha di Indonesia, kartel dibagi menjadi 3 jenis, yaitu kartel harga, kartel wilayah, dan kartel kuota.

c. Sukarmi

Pada prakteknya selama ini yang terjadi Leniency Program akan memberikan insentif untuk pelaku kartel. 
Dalam RUU tentang Larangan Praktik Monopoli dan Persaingan Usaha Tidak Sehat, khususnya pada pasal-pasal mengenai Leniency Program memiliki cakupan yang luas, dibandingkan dengan Leniency Program di negaranegara lain. Dalam RUU tersebut terdapat 11 pasal yang dapat diberikan Leniency Program, antara lain (Sukarmi, 2011): Oligopoli/pasal 4 UU No. 5 Thn 1999; Perjanjian Penetapan Harga/pasal 5 UU No. 5 Thn 1999; Jual Rugi/ pasal 7 UU No. 5 Thn 1999; Pembagian Wilayah/pasal 9 UU No. 5 Thn 1999; Pemboikotan/ pasal 10 UU No. 5 Thn 1999; Kartel/ pasal 11 UU No. 5 Thn 1999; Trust/Pasal 12 UU No. 5 Thn 1999; Oligopsoni/ pasal 13 UU No. 5 Thn 1999; Perjanjian Tertutup/Pasal 15 UU No. 5 Thn 1999; Perjanjian Dengan Pihak Luar Negeri/ pasal 16 UU No. 5 Thn 1999; Monopsoni/pasal 18 UU No. 5 Thn 1999.

Karakteristik kartel yang sangat kental dengan unsur kerahasiaan, para pelaku usaha yang ingin mendapatkan keuntungan dengan jalan pintas, akan memilih untuk melakukan kerjasama curang dengan pelaku usaha lainnya agar mereka dapat mendapatkan konsumen tanpa melakukan persaingan. Nampaknya, hal ini sering dilupakan oleh pembuat pasal di bidang persaingan usaha. Sebelas rumusan pasal yang terdapat di RUU tidak semuanya cocok untuk diberikan Leniency Program, Leniency Program hanya dapat diberikan untuk pelanggaran yang berat dan khusus agar penerapannya berjalan maksimal.

Rumusan pasal dalam RUU tersebut, sebaiknya diganti sebagai berikut: pengampunan dan/ atau pengurangan hukuman akan diberikan oleh KPPU terhadap pelanggaran ketentuan Pasal 4, Pasal 9 dan Pasal 11. Ketentuan lebih lanjut akan diatur dalam Peraturan Pemerintah.

\section{Jenis-Jenis Leniency Program}

Leniency Program bagi perusahaan yang bersedia bekerjasama dengan penegak hukum dan bersedia mengakui adanya kartel akan diberikan pengurangan denda administrasi: Pihak pertama yang melapor: denda administrasi akan dikurangi $30 \%-50 \%$. Pihak kedua yang melapor: $25 \%$ - 40\%. Pihak ketiga yang melapor: $25 \%$.

Leniency Program bagi individu-individu dalam perusahaan yang bersedia bekerjasama dengan penegak hukum dan bersedia memberikan informasi tentang adanya kartel akan diberikan insentif.

Perhitungan presentase denda tersebut berdasarkan hasil rapat di tingkat panitia Kerja (Panja), yang untuk selanjutnya akan diumumkan dalam sidang komisi untuk dibawa ke Badan Legislatif DPR RI. Menurut Syarkawi Rauf, adanya peningkatan sanksi bagi pelaku usaha yang terbukti melakukan kartel berupa denda sebesar 5\% sampai dengan 30\% dari hasil penjualan bertujuan untuk efek jera.

Paper yang dibuat oleh Young Council Latin American Regional Forum International Bar Association dengan Tema Leniency: The Future for Cartel Enforcement in Latin America, Berdasarkan The Brazilian Competition Law, pelanggaran terhadap praktek persaingan yang dilakukan oleh subjek hukum perusahaan akan mendapatkan denda sampai dengan 20\%. Bagi perusahaan privat yang tidak mempunyai data penjualan dan tidak ikut bergabung dengan asosiasi perusahaan yang lainnya denda yang dikenakan sebesar USD $\$ 15,000$ (BRL 50,000) to USD\$ 600 million (BRL 2,000,000,000) (Young Council, 2016).

Penanggung jawab atas tindakan di dalam suatu perusahaan adalah pihak direktur baik secara langsung ataupun tidak langsung bertanggungjawab atas pelanggaran terhadap persaingan dapat juga menjadi subjek yang dapat dikenakan sanksi denda sebesar $1 \%$ sampai dengan $20 \%$ sesuai dengan sanksi denda yang dikenakan kepada perusahaannya. Jadi, sanksi denda yang dikenakan untuk individu sangat tergantung kepada sanksi denda yang dikenakan kepada perusahaan. Dan, ketika perusahaan tersebut melakukan pelanggar- 
an ulang, maka sanksi denda akan meningkat menjadi dua kali lipat.

Dibawah pengaturan Brazilian Competetition Law, terdapat perbedaan mengenai presentase denda yang dikenakan bagi pelaku kartel yang mengajukan Leniency Agreement, antara lain sebagai berikut:

Pihak pertama yang mengajukan Leniency Agreement akan menerima secara penuh kekebalan administratif dan pidana, asalkan sesuai dengan persyaratan-persyaratan yang telah ditentukan. Salah satu persyaratannya adalah The Administrative Council for Economic Defense (CADE) tidak memiliki informasi tentang pelanggaran yang sedang dilaporkan. Apabila CADE telah memiliki pengetahuan tentang pelanggaran tersebut, namun belum memiliki bukti yang cukup untuk menghukum pelaku kartel, pemohon leniency agreement dapat memperoleh pengurangan $1 / 3$ sampai dengan 2/ 3 dari dari sanksi denda yang dikenakan kepadanya, walaupun otomatis secara individu masih menerima kekebalan pidana.

Pihak yang lainnya yang akan mengajukan Leniency Agreement harus menandatangani The Cease and Desist Agreement (TCC). Terdapat persyaratanpersyaratan yang harus dipenuhi pada saat mengajukan TCC ini, antara lain: Mengakui partisipasinya dalam pelanggaran persaingan usaha. Memiliki komitmen untuk bekerjasama selama investigasi. Membayar biaya kontribusi.

Besaran presentase potongan denda yang akan diberikan bermacam-macam, antara lain: Sebesar 30\% sampai dengan 50\% untuk pihak pertama yang bekerjasama; Sebesar 25\% sampai dengan $40 \%$ untuk pihak kedua yang bekerjasama; Sampai 25\% untuk pihak yang selanjutnya.

Berdasarkan pemaparan diatas, nampak adanya persamaan besaran potongan denda di Indonesia dan Brazil. Di Brazil, perhitungan denda tersebut dapat dikatakan sudah cukup ideal, dari 70 kasus kartel yang telah terjadi di Brazil, 54 dian- taranya berhasil diselesaikan dengan Leniency Program.

\section{Prosedur Pengajuan Leniency Agreement}

Langkah pertama mengajukan Leniency adalah menghubungi KPPU secara rahasia, untuk menentukan apakah sudah ada marker tersedia dalam kasus tertentu. Jika marker tersedia, langkah selanjutnya adalah mengajukan permintaan penanda. KPPU memiliki waktu 3 (tiga) hari untuk menerbitkan marker atau untuk mengabaikan permintaan tersebut. Penanda berlaku selama 30 hari. Namun, KPPU dapat melakukan pembaharuan terhadap marker, memberikan waktu tambahan kepada pelamar untuk mempersiapkan aplikasi mereka. Ada periode negoisasi 6 bulan. Setelah negosiasi proses selanjutnya adalah penandatanganan Leniency Agreement, proses penyelidikan dan prosedur pendaftaran secara formal. Keputusan terakhir berada di tangan KPPU, apakah pelamar layak mendapat Leniency Agreement.

Dari uraian diatas, pengaturan Leniency Program di Indonesia diharapkan dapat memuat ketentuan-ketentuan, antara lain: Pertama, tujuantujuan pengaturan Leniency Program di Indonesia, Kedua, definisi-definisi istilah-istilah dalam hukum persaingan usaha (istilah pelaku usaha, istilah persaingan usaha yang tidak sehat, istilah Leniency Program), Ketiga, Ruang Lingkup dari Leniency Program dan Keempat, Jenis-Jenis Leniency Program, dan Keempat, Prosedur Pengajuan Leniency Program (Leniency Agreement).

\section{Simpulan}

Pengaturan Leniency Program di Indonesia, seharusnya mengatur beberapa ketentuanketentuan, antara lain: tujuan pengaturan Leniency Program di Indonesia, definisi-definisi dalam bidang hukum persaingan usaha (pelaku usaha, persaingan usaha yang tidak sehat, dan Leniency Program), ruang lingkup Leniency Program di Indonesia, dan yang terakhir prosedur pengajuan Leniency Program. 


\section{Jurnal Cakrawala Hukum, Volume 9 No. 2 Desember 2018}

ISSN PRINT 2356-4962 ISSN ONINE 2598-6538

\section{Daftar pustaka}

Brazilian Antitrust Law No. 8884 of June 11, 1994.

$\mathrm{HIR} / \mathrm{RBg}$.

Komisi Pengawas Persaingan Usaha, Peraturan Komisi Pengawas Persaingan Usaha Nomor 04 Tahun 2010 tentang Pedoman Pasal 11 tentang Kartel.

Law No. 10149 of 21 th of December 2000.

Law No. 12,529 of November 30, 2011.

Maria, Anna dan Tri Anggraini. 2011. Penggunaan Analisis Ekonomi dalam Mendeteksi Kartel Berdasarkan Hukum Persaingan Usaha. Jurnal Persaingan Usaha KPPU. Edisi 4.

Muladi dan Barda Nawawi. 2005. Teori-Teori dan Kebijakan Pidana. Bandung. Alumni.

Munalidya, Riris. Bukti Tidak Langsung (Indirect Evidence) dalam Penanganan Kasus Persaingan Usaha. Jurnal Persaingan Usaha. Edisi 5 Tahun 2011.

OECD. 2006. Prosecuting Cartels Without Direct Evidence. https://www.oecd.org/daf/competition/ prosecutionandlawenforcement/37391162.pdf, (online), 23 Maret 2018.

Peraturan Mahkamah Agung Nomor 03 Tahun 2005 tentang Tata Cara Pengajuan Keberatan Terhadap Putusan KPPU.

Putusan KPPU No. 04 Tahun 2016 tentang Kartel Yamaha dan Honda.

Putusan KPPU No. 08 Tahun 2014 tentang Kartel Ban.

Putusan KPPU No. 10 Tahun 2015 tentang Kartel Daging Sapi Impor.

Putusan KPPU No. 17 Tahun 2010 tentang Kartel Obat Hipertensi.

Putusan KPPU No. 24 Tahun 2009 tentang Kartel Minyak Goreng.

Putusan KPPU No. 25 Tahun 2009 tentang Kartel Fuel Surcharge.
Putusan Mahkamah Agung No. 613 K/Pdt.Sus/2011.

Putusan Mahkamah Agung Nomor 294 K/Pdt.Sus/ 2012.

Putusan Mahkamah Agung Nomor 582/K/PDT.SUS/ 2011.

Putusan PN Jakarta Pusat No. 05/Pdt.KPPU/2010/ PN.JKT.PST.

Putusan PN Jakarta Pusat Nomor 02/KPPU/2010/PN. JKT.PST.

Putusan PN Jakarta Pusat Nomor 03/KPPU/2010/ PN.JKT.PST.

Rachman, Miftahur. Leniency Program Sebagai Upaya Memberantas Kartel dalam Hukum Persaingan Usaha di Indonesia. Jurnal Business Law Review. Volume 3.

Saputri, Alia. 2010. KPPU \& OECD KPC Workshop: Workshop on Cartel and Market Definition. Majalah Kompetisi. Edisi 22. Tahun 2010.

Secretariat of Economic Law Antitrust Division Council for Economic Defense. 2009. Fighting Cartels: Brazil's: Leniency Program. Secretariat of Economic Law, Antitrust Division Council of Economic Defense.

Sukarmi, Pembuktian Kartel dalam Hukum Persaingan Usaha. Jurnal Persaingan Usaha KPPU. Edisi 6 Tahun 2011.

Undang-Undang 8 Tahun 1981 tentang Hukum Acara Pidana.

Undang-Undang Nomor 5 Tahun 1999 tentang Larangan Praktik Monopoli dan Persaingan Usaha yang Tidak Sehat.

Usman, Rachmadi. 2013. Hukum Persaingan Usaha di Indonesia. Jakarta. Gramedia Pustaka Utama.

Yani, Ahmad. 2013. Pembentukan Peraturan PerundangUndangan yang Responsif. Jakarta. Konstitusi Press. 